\title{
HUBUNGAN ANTARA KEBUGARAN JASMANI DENGAN KUALITAS TIDUR
}

\author{
Ellen Safaringga ${ }^{1}$ dan Reo Prasetiyo Herpandika ${ }^{2}$ \\ ${ }^{1,2}$ Penjaskesrek Universitas Nusantara PGRI Kediri \\ E-mail: ellensafaringga95@gmail.com ${ }^{1}$,reoprasetiyo@unpkediri.ac.id ${ }^{2}$ \\ Diterima: 17 September 2018; Lolos: 16 November 2018; Dipublikasikan: 17 November 2018 \\ DOI: https://doi.org/10.29407/js_unpgri.v4i2.12467
}

\begin{abstract}
Abstrak
Penelitian ini bertujuan untuk mengetahui hubungan kebugaran jasmani dengan kualitas tidur. Pendekatan penelitian yang digunakan adalah kuantitatif, dengan menggunakan teknik korelasi. Populasi dalam penelitian adalah mahasiswa angkatan 2014 program studi Penjaskesrek Universitas Nusantara PGRI Kediri sejumlah 192 mahasiswa. Sampel dalam penelitian diambil sebanyak 38 mahasiswa penjaskesrek angkatan 2014. Teknik yang digunakan dalam pengambilan sampel random sampling. Berdasarkan hasil penelitian, diperoleh nilai $r_{\text {hitung }}$ sebesar $=0,408>r_{\text {tabel }}=0,320$ dengan nilai sig. 0,011<0,05 (taraf signifikan $5 \%$ ) maka $\mathrm{H}_{0}$ ditolak yang artinya ada korelasi yang signifikan antara aktivitas kebugaran jasmani dengan kualitas tidur. Kesimpulannya adalah tingkat kebugaran jasmani memiliki hubungan yang rendah dengan kualitas tidur.
\end{abstract}

Kata kunci: Aktivitas, kebugaran jasmani, kualitas tidur.

THE RELATIONSHIP BETWEEN PHYSICAL FITNESS AND SLEEP QUALITY

\begin{abstract}
This study aims to determine the relationship of physical fitness with sleep quality. The research approach used is quantitative, using correlation techniques. The populationin this study were 192 students of 2014 study program Penjaskesrek Nusantara Nusantara University PGRI. The sample in the study was taken as many as 38 class of 2014 penjaskesrek students. The technique used in sampling random sampling. Based on the results of the study, obtained the value of $r$ count $=0.408>r$ table $=0.320$ with the value of sig. $0.011<0.05$ (significant level of 5\%) then $\mathrm{HO}$ is rejected which means that there is a significant correlation between physical fitness activities and sleep quality. The conclusion is that the level of physical fitness has a strong enough relationship with sleep quality.
\end{abstract}

Keywords: Activity, physical fitness, sleep quality.

\section{PENDAHULUAN}

Aktivitas fisik tidak terlepas dari pengaruh kebugaran jasmani, dimana dalam setiap aktivitas yang dilakukan secara rutin dan mempunyai tingkatan aktivitas yang stabil juga akan berpengaruh dengan kebugaran jasmani. Kebugaran jasmani merupakan kemampuan seseorang untuk melakukan kegiatan sehari-hari dengan mudah tanpa merasa lelah dan

Email : reoprasetiyo@unpkediri.ac.id

No Handphone : 085330237373
(C)2018 UN PGRI Kediri

p-ISSN: 2548-7833

e-ISSN: 2477-3379 
masih mempunyai sisa atau cadangan tenaga untuk menikmati waktu senggang atau untuk keperluan yag sewaktu-waktu dapat digunakan, dengan demikian kebugaran jasmani merupakan wujud dari loyalitas fungsional seseorang untuk melakukan suatu pekerjaan secara tertentu dengan hasil yang baik atau memuaskan (Wirnantika, Pratama, \& Hanief, 2017).

Sedangkan pada umumnya manusia juga membutuhkan istirahat dengan cara tidur untuk mengembalikan kebugaran ataupun sekedar mengistirahatkan organ-organ tubuh setelah melakukan aktivitas olahraga. Pada kondisi tidur, tubuh melakukan proses pemulihan untuk mengembalikan stamina tubuh hingga berada dalam kondisi yang optimal (Sarfriyanda, Karim, \& Dewi, 2015).

Jika seseorang mengeluhkan kendala-kendala seperti kesulitan tidur, tidur tidak tenang, kesulitan menahan tidur, seringnya terbangun dipertengahan malam, dan seringnya terbangun lebih awal, kemungkinan orang tersebut terganggu kualitas tidurnya. Menurut Sulistiyani (2012) kualitas tidur adalah kemampuan individu untuk dapat tetap tidur, tidak hanya mencapai jumlah atau lamanya tidur. Kualitas tidur menunjukkan adanya kemampuan individu untuk tidur dan memperoleh jumlah istirahat yang sesuai dengan kebutuhannya.

Gangguan tidur menyerang siapa saja dan kapan saja. Seperti halnya mahasiswa semester VII Program Studi Penjaskesrek Universitas Nusantara PGRI Kediri yang berjumlah 192 mahasiswa. Mereka (mahasiswa semester VII) menempuh 24 sks, sehingga menyebabkan padatnya aktivitas perkuliahan. Dari hal-hal tersebut mahasiswa akan mengalami siklus aktivitas yang tetap dan padat karena dilaksanakan selama enam hari selama seminggu. Dengan aktivitas yang begitu padat mahasiswa kemungkinan mempunyai masalah dalam kebugaran jasmani dan juga kualitas tidurnya. Hal ini diperkuat dengan beberapa mahasiswa semester VII yang sering mengeluhkan kelelahan dikarenakan aktivitasnya yang sangat padat. Sarfriyanda et al. (2015) 
menambahkan,"Faktor yang dapat mempengaruhi kualitas tidur seseorang termasuk juga kelelahan".

Kelelahan berbanding terbalik dengan kualitas tidur yang dialami seseorang. Semakin tinggi tingkat kelelahan yang dialami seseorang, maka kualitas tidurnya pun semakin buruk. Kebutuhan tidur pada usia dewasa awal berkisar 7 sampai 9 jam, namun ternyata sekitar 6 jam sehari karena faktor aktifitas dan kehidupan sosial. Hal ini akan memberikan pengaruh terhadap waktu tidur (Sarfriyanda et al., 2015).

Penelitian di Indonesia yang dilakukan oleh Japardi yang dituliskan dalam penelitian Adeleyna yang berjudul "Analisis insomnia pada mahasiswa melalui model pengaruh kecemasan tes" menyatakan bahwa hampir semua orang pernah mengalami gangguan tidur selama masa hidupnya, diperkirakan setiap tahunnya 20 - 40\% orang dewasa mengalami kesukaran tidur dan 17\% diantaranya mengalami masalah serius (Rizqia \& Hartati, 2012). Sebanyak 28,053 juta orang Indonesia yang mengalami gangguan tidur atau sekitar 11,7\%. 10\% dialami oleh kalangan remaja Data ini hanya berdasarkan indikasi secara umum tidak memperhitungkan faktor genetik, budaya, lingkungan, sosial, dan ras. Jumlah ini bisa terus bertambah seiring dengan perubahan gaya hidup (Nugroho, 2016).

Pada tahun 2011, survei rutin dilakukan sejak 1991 oleh National Sleep Foundation itu melibatkan 1.508 responden. Responden dibagi dalam 4 kelompok yakni usia 13-18 tahun, 19-29 tahun, 30-45 tahun dan 46-64 tahun. Sebagian besar responden mengaku tidak pernah atau jarang tidur pulas pada hari bekerja atau sekolah, dengan prosentase tertinggi yakni sekitar 51\% pada usia 19-29 tahun (Sulistiyani, 2012).

Kualitas tidur seseorang dapat dipengaruhi oleh beberapa faktor, diantaranya yaitu kondisi lingkungan, fisik, aktivitas, dan gaya hidup. Kebiasaan olahraga merupakan bentuk aktivitas fisik yang dapat mempengaruhi tidur seseorang (Sulistiyani, 2012).

Keletihan yang terjadi setelah melakukan aktivitas olahraga akan menimbulkan seseorang akan cepat tertidur. Hal ini juga disebabkan oleh 
siklus tidur tahap gelombang lambatnya diperpendek, sehingga akan lebih cepat masuk fase kedalaman tidur atau mengalami tidur yang nyenyak. Sedangkan, perilaku merokok juga dapat menyebabkan masalah tidur, hal ini terkait nikotin yang terkandung dalam rokok yang merupakan stimulan otak. Disamping itu, otak yang telah kecanduan dengan efek nikotin akan menyebabkan gangguan tidur pada malam hari saat akan tidur (Sulistiyani, 2012).

Kebugaran jasmani erat kaitannya dengan aktivitas fisik. Setiap manusia memiliki aktivitas fisik yang berbeda, otomatis kebugaran jasmaninya pun berbeda. Semakin banyak aktivitas fisik yang dilakukan maka tingkat kebugaran jasmaninya akan semakin tinggi. Hal ini sesuai dengan penelitian yang dilakukan oleh Erwinanto (2017) yang menunjukkan adanya korelasi antara aktivitas fisik dengan kebugaran jasmani meskipun kekuatan kedua variabel rendah.

Penelitian ini bertujuan untuk mendapatkan informasi ada tidaknya hubungan antara kebugaran jasmani dengan kualitas tidur. Penelitian serupa telah dilakukan oleh Sutri (2014) dengan judul "Hubungan Aktivitas Fisik dengan Kesegaran Jasmani Pada Remaja Puasa", namun dalam penelitian tersebut disimpulkan tidak ada hubungan yang signifikan antara aktivitas fisik dengan kesegaran jasmani.

Penelitian ini merupakan pengembangan dari penelitian terdahulu untuk menjawab dengan pasti ada tidaknya hubungan antara kebugaran jasmani dengan kualitas tidur. Dengan hasil penelitian ini diharapkan mendapatkan hasil positif untuk dapat dijadikan sebagai wawasan tentang pentingnya kualitas tidur seseorang.

\section{METODE}

Penelitian ini merupakan penelitian korelasi. Data kebugaran jasmani diperoleh dengan menggunakan tes Multistage Fitness Test (MFT), sementara data kualitas tidur diperoleh dengan menggunakan angket. Populasi dalam penelitian ini adalah seluruh mahasiswa putra angkatan 2014 program studi Penjaskesrek Universitas Nusantara PGRI Kediri yang berjumlah 192 mahasiswa. Sedangkan sampel pada 
penelitian ini berjumlah 38 mahasiswa. Teknik pengambilan sampel dari populasi memakai teknik random sampling, dimana peneliti "mencampur" subjek-subjek didalam populasi sehingga semua subjek dianggap sama.

Instrumen yang digunakan dalam penelitian ini ada dua yaitu Multistage Fitness Test (MFT) untuk mengukur kebugaran jasmani dan kuisoner The Pittsburgh Sleep Quality Index (PSQI) untuk mengukur kualitas tidur.

Perhitungan VO2 Max dengan menggunakan tes MFT (Multistage Fitness Test) dapat dilihat pada tabel 1 berikut ini :

Tabel 1. Norma Kebugaran untuk Lelaki Berdasarkan Kelompok Umur (www.aerobictest.com/FitnessNorms.htm)

\begin{tabular}{cccc}
\hline No & Status & $\mathbf{1 8 - 2 5}$ Tahun & $\mathbf{3 6 - 3 5}$ Tahun \\
\hline 1 & Sangat Bugar & $>60$ & $>56$ \\
\hline 2 & Bugar & $52-60$ & $49-56$ \\
\hline 3 & Di atas Rata-Rata & $47-51$ & $43-48$ \\
\hline 4 & Rata-Rata & $42-46$ & $40-42$ \\
\hline 5 & Dibawah Rata-Rata & $37-41$ & $35-39$ \\
\hline 6 & Tidak Bugar & $30-36$ & $30-34$ \\
\hline 7 & Sangat Tidak Bugar & $<30$ & $<30$ \\
\hline
\end{tabular}

The Pittsburgh Sleep Quality Index (PSQI)

Menurut Buysee, dkk dalam Rush (2000) PSQI adalah instrumen yang paling efektif untuk digunakan untuk mengukur kualitas tidur dan pola tidur seseorang. PSQI dikembangkan untuk mengukur dan membedakan individu dengan kualitas tidur yang baik dan kualitas tidur yang buruk. Kualitas tidur merupakan fenomena yang kompleks dan melibatkan beberapa dimensi yang seluruhnya dapat tercangkup dalam PSQI. Dimensi tersebut dinilai dalam bentuk pertanyaan dan memiliki bobot penilaian masing-masing sesuai dengan standar buku. PSQI terdiri dari tujuh pertanyaan yang diberi nilai dan dijawab oleh individu itu sendiri. Penentuan kualitas tidur yang baik atau buruk dilakukan dengan mengukur tujuh area yaitu : a) Sleep latensi, b) Durasi tidur, c) Penggunaan obat tidur, d) Gangguan tidur, e) Disfungsi tidur pada siang hari, f) Efisiensi kebiasaan tidur, g) Kualitas tidur subjektif.

Validitas penelitian dari PSQI sudah teruji Penelitian ini menghasilkan uji konsistensi internal Cronbachs Alpha $=0.79$, validitas isi 
0.89, validitas konstruksi menunjukkan korelasi komponen dengan skor global PSQI yang baik, known group validity bermakna ( $p<0.001)$, nilai sensitivitas adalah satu, spesifisitas 0.81 , titik potong 5. Instrumen PSQI terbukti kesahihan dan keandalannya. Instrumen ini menghasilkan tujuh skor yang sesuai dengan domain area yang disebutkan sebelumnya. Dalam menentukan kualitas tidur, jawaban tiap pertanyaan dijumlahkan kemudian disesuaikan dengan kategori tertentu.

Tabel 2. Kategori penilaian

\begin{tabular}{ccc}
\hline No & Kriteria & Nilai \\
\hline 1 & Sangat setuju & $\mathbf{3}$ \\
\hline 2 & Setuju & $\mathbf{2}$ \\
\hline 3 & Agak setuju & $\mathbf{1}$ \\
\hline 4 & Tidak setuju & $\mathbf{0}$ \\
\hline
\end{tabular}

(Sumber: YI, SHIN, \& SHIN, 2006)

Tabel 3. Norma Skala PSQI

\begin{tabular}{ccc}
\hline No & Skor & Kriteria \\
\hline 1 & $0-5$ & Tidak ada masalah \\
\hline 2 & $6-10$ & Masalah ringan \\
\hline 3 & $11-15$ & Masalah sedang \\
\hline 4 & $16-21$ & Masalah berat \\
\hline
\end{tabular}

(Sumber: (Yl et al., 2006)

Tabel 4. Interpretasi Nilai Koefisien Korelasi ( $r$ )

\begin{tabular}{cc}
\hline Nilai $\mathbf{r}$ & Interpretasi \\
\hline 0,900 s.d. $1.000(-0,900 \mathrm{~s}, \mathrm{~d},-1,000)$ & Korelasi $(+/-)$ Sangat Tinggi \\
\hline 0,700 s.d. $0.900(-0,700 \mathrm{~s}, \mathrm{~d},-0,900)$ & Korelasi $(+/-)$ Tinggi \\
\hline 0,500 s.d. $0.700(-0,500 \mathrm{~s}, \mathrm{~d},-0,700)$ & Korelasi $(+/-)$ Sedang \\
\hline 0,300 s.d. $0.500(-0,300 \mathrm{~s}, \mathrm{~d},-0,500)$ & Korelasi $(+/-)$ Rendah \\
\hline 0,000 s.d. $0.300(-0,000 \mathrm{~s}, \mathrm{~d},-0,300)$ & Korelasi $(+/-)$ Tidak Berarti \\
\hline
\end{tabular}

(Sumber: Hanief \& Himawanto, 2017)

Teknik analisis data yang cocok digunakan untuk pengujian hipotesis yaitu Korelasi Product Moment (Hanief \& Himawanto, 2017). Untuk mengetahui apakah koefisien korelasi hasil perhitungan signifikan atau tidak, maka perlu dibandingkan dengan $r$ tabel Product Moment, dengan taraf kesalahan 5\% (taraf kepercayaan 95\%). 


\section{HASIL DAN PEMBAHASAN}

\section{Hasil}

1. Deskripsi Data Aktivitas Kebugaran Jasmani

Intrumen yang digunakan untuk mengukur aktivitas kebugaran jasmani yaitu Multistage Fitness Test (MFT). Adapun hasil tes dapat dilihat pada tabel deskripsi berikut ini.

Tabel 5. Statistik Deskripsi Multistage Fitness Test (MFT).

\begin{tabular}{|c|c|c|c|c|c|}
\hline & $N$ & Minimur & Maximum & Mean & Std. Deviation \\
\hline $\begin{array}{c}\text { Aktivitas } \\
\text { Kebugaran } \\
\text { Jasmani }\end{array}$ & 38 & 30.00 & 40.00 & 35.1316 & 2.44033 \\
\hline Valid $N$ (listwise) & 38 & & & & \\
\hline
\end{tabular}

Berdasarkan hasil tabel 5 di atas diperoleh nilai rata-rata sebesar 35.1316 dengan standar deviasi 2.44033 sedangkan skor tertinggi sebesar 40 dan skor terendah sebesar 30. Apabila hasil deskripsi di atas disesuaikan dengan berdasarkan norma kebugaran untuk lelaki berdasarkan kelompok umur adalah sebagai berikut:

Tabel 6. Tingkat Kebugaran Jasmani

\begin{tabular}{cccc}
\hline Nilai & Kriteria & Frekuensi & Persentase (\%) \\
\hline$>60$ & Sangat bugar & 0 & 0 \\
\hline $52-60$ & Bugar & 0 & 0 \\
\hline $47-51$ & Di atas rata-rata & 0 & 0 \\
\hline $42-46$ & Rata-rata & 0 & 0 \\
\hline $37-41$ & Dibawah rata-rata & 12 & 31,6 \\
\hline $31-36$ & Tidak bugar & 24 & 63,2 \\
\hline$<30$ & Sangat tidak bugar & 2 & 5,2 \\
\hline & Total & $\mathbf{3 8}$ & $\mathbf{1 0 0}$ \\
\hline
\end{tabular}

Dari tabel 6 di atas diketahui bahwa perolehan nilai terbanyak yaitu 30-36 terdapat 24 mahasiswa (63,2\%) memiliki kriteria tidak bugar, sedangkan perolehan nilai 37-41 sebanyak 12 mahasiswa (31,6\%) memiliki kriteria di bawah rata-rata dan perolehan nilai $<30$ sebanyak 2 mahasiswa $(5,2 \%)$ memiliki kriteria sangat tidak bugar. 


\section{Deskripsi Data Kualitas Tidur}

Instrumen yang digunakan untuk mengukur kualitas tidur menggunakan kuesioner The Pittsburgh Sleep Quality Index (PSQI). Adapun hasil tes dapat dilihat pada tabel deskripsi berikut ini:

Tabel 7. Statistik Deskriptif The Pittsburgh Sleep Quality Index (PSQI).

\begin{tabular}{cccccc}
\hline & $N$ & Minimum & Maximum & Mean & Std. Deviation \\
\hline Kualitas Tidur & 38 & 13.00 & 20.00 & 16.6842 & 1.86149 \\
\hline Valid N (listwise) & 38 & & & & \\
\hline
\end{tabular}

Berdasarkan hasil tabel 7 diperoleh nilai rata-rata sebesar 16.6842 dengan standar deviasi 1.86149 sedangkan skor tertinggi sebesar 20 dan skor terendah sebesar 13 dari sebanyak 38 mahasiswa. Apabila hasil deskripsi di atas dibuat berdasarkan norma skala PSQI adalah sebagai berikut:

Tabel 8. Norma Skala PSQI untuk Kualitas Tidur

\begin{tabular}{cccc}
\hline Nilai & Kriteria & Frekuensi & Persentase (\%) \\
\hline $0-5$ & Tidak ada masalah & 0 & 0 \\
\hline $6-10$ & Masalah ringan & 0 & 0 \\
\hline $11-15$ & Masalah sedang & 10 & 26,3 \\
\hline $16-21$ & Masalah berat & 28 & 73,7 \\
\hline & Total & $\mathbf{3 8}$ & $\mathbf{1 0 0}$ \\
\hline
\end{tabular}

Dari tabel 8 di atas diketahui bahwa perolehan nilai terbanyak yaitu 16-21 terdapat 28 mahasiswa $(73,7 \%)$ dengan kriteria masalah berat, sedangkan perolehan nilai 11-15 sebanyak 10 mahasiswa (26,3\%) memiliki kriteria masalah sedang.

3. Hasil Analisis Data Hubungan antara Aktivitas Kebugaran Jasmani dengan Kualitas Tidur

Sebagai kriteria pengujian, jika nilai $r_{\text {hitung }}>r_{\text {tabel }}$ dengan sig. (2tailed) lebih kecil dari 0,05 maka dapat dikatakan bahwa ada hubungan yang signifikan dan apabila nilai $r_{\text {hitung }}<r_{\text {tabel }}$ dengan sig. (2-tailed) lebih besar dari 0,05 maka dapat dikatakan bahwa tidak ada hubungan yang signifikan. Adapun hasil dari perhitungan analisis data korelasi product moment dapat disajikan pada tabel sebagai berikut: 
Tabel 9. Korelasi Product Moment

\begin{tabular}{cccc}
\hline & & $\begin{array}{c}\text { Aktivitas Kebugaran } \\
\text { Jasmani }\end{array}$ & Kualitas Tidur \\
\hline \multirow{2}{*}{$\begin{array}{c}\text { Aktivitas } \\
\text { Kebugaran } \\
\text { Jasmani }\end{array}$} & $\begin{array}{c}\text { Pearson } \\
\text { Correlation }\end{array}$ & 1 & $.408^{*}$ \\
\cline { 2 - 4 } & Sig. (2-tailed) & & .011 \\
\cline { 2 - 4 } & $N$ & 38 & 38 \\
\hline \multirow{3}{*}{ Kualitas Tidur } & $\begin{array}{c}\text { Pearson } \\
\text { Correlation }\end{array}$ & $.408^{*}$ & 1 \\
\cline { 2 - 4 } & Sig. (2-tailed) & .011 & 38 \\
\cline { 2 - 4 } & $N$ & 38 & \\
\hline
\end{tabular}

${ }^{\star}$. Correlation is significant at the 0.05 level (2-tailed).

Berdasarkan hasil analisis data pada tabel 9 diketahui bahwa sampel 38 (taraf sig. $5 \%$ ) diperoleh nilai $r_{\text {tabel }}$ sebesar $=0,320$ sedangkan dari hasil uji $r_{\text {hitung }}$ diperoleh nilai sebesar 0,408 dengan sig. (2-tailed) 0,011 artinya $t_{\text {hitung }}>\mathrm{r}_{\text {tabel }}$ dengan sig. (2-tailed) $<0,05$ maka $\mathrm{H}_{0}$ ditolak artinya ada hubungan yang signifikan antara aktivitas kebugaran jasmani dengan kualitas tidur dengan korelasi / hubungan sebesar 0,408 dengan kriteria rendah.

\section{PEMBAHASAN}

Korelasi antara kebugaran jasmani dengan kualitas tidur pada mahasiswa prodi Penjaskesrek Universitas Nusantara PGRI Kediri angkatan 2014 putra dapat disimpulkan memiliki korelasi yang rendah, hal ini dapat diketahui bahwa perolehan nilai $r_{\text {hitung }}=0,408$ dan $r_{\text {tabel }}=0,320(\mathrm{~N}$ $=38$ sig. $5 \%$ ) dengan sig. (2-tailed) 0,011 $<0,05$ maka $\mathrm{H}_{0}$ ditolak artinya ada hubungan antara kebugaran jasmani dengan kualitas tidur dengan koefisien korelasi sebesar 0,408 dengan kriteria rendah.

Dengan demikian kebugaran jasmani yang cukup dapat mempengaruhi kualitas tidur seseorang dapat terpenuhi, begitu sebaliknya bila tingkat kebugaran jasmani kurang baik maka kualitas tidur seseorang akan berkurang. Dari hasil penelitian bahwa tingkat kebugaran jasmani pada mahasiswa mayoritas pada kategori tidak bugar yaitu sebanyak 24 
$(63,2 \%)$ sedangkan sebanyak $12(31,6 \%)$ dibawah rata-rata dan sisanya sebanyak $2(5,2 \%)$ sangat tidak bugar.

Sesuai dengan hasil pengamatan awal bahwa mahasiswa jurusan Penjaskesrek semester akhir memiliki kegiatan perkuliahan yang sangat padat sehingga waktu untuk melakukan olahraga fisik jarang dilakukan akibatnya para mahasiswa memiliki tingkat kebugaran jasmani yang tidak baik artinya faktor yang mempengaruhinya adalah faktor kegiatan fisik dengan kurangnya olahraga maka tingkat kebugaran jasmaninya negatif. Sesuai pendapat Wirnantika et al. (2017) bahwa kemampuan seseorang untuk melakukan kegiatan sehari-hari dengan mudah tanpa merasa lelah dan masih mempunyai sisa atau cadangan tenaga untuk menikmati waktu senggang atau untuk keperluan yag sewaktu-waktu dapat digunakan, dengan demikian kebugaran jasmani merupakan wujud dari loyalitas fungsional seseorang untuk melakukan suatu pekerjaan secara tertentu dengan hasil yang baik atau memuaskan. Senada dengan hasil penelitian lqbal (2017) yang menunjukkan bahwa terdapat hubungan yang signifikan $(p>0.05)$ antara aktivitas fisik dengan kualitas tidur yang mana subyek yang aktif dalam beraktivitas fisik mempunyai peluang mendapatkan kualitas tidur yang baik 4.136 kali lebih tinggi dibandingkan dengan subyek yang tidak aktif. Aktivitas fisik berhubungan dengan kebugaran kardiorespirasi anak-anak dan remaja (World Health Organization, 2010).

Berdasarkan hasil yang diperoleh bahwa tingkat kebugaran jasmani pada mahasiswa mayoritas pada kategori tidak bugar hal ini dapat berakibat terdapat kualitas tidur seseorang. Dari hasil penelitian yang telah dilakukan bahwa rata-rata kualitas tidur para mahasiswa mengalami masalah berat bahwa sebanyak 28 (73,7\%) mahasiswa mengalami kualitas tidur yang buruk artinya pada mahasiswa mengalami masalah berat. Sedangkan sisanya sebanyak $10(26,3 \%)$ mahasiswa mengalami masalah sedang. Kualitas tidur yang buruk para mahasiswa dipengaruhi oleh faktor aktivitas fisik bahwa mahasiswa tingkat akhir jarang melakukan kegiatan fisik atau olahraga. 
Tidur merupakan suatu keadaan tidak sadar dimana persepsi dan reaksi individu terhadap lingkungan menurun atau hilang, dan dapat dibangunkan kembali dengan indra atau rangsangan yang cukup (Asmadi, 2008). Faktor kualitas tidur sebenarnya dipengaruhi oleh banyak faktor. Wicaksono (2012) dalam penelitiannya yang berjudul analisis faktor dominan yang berhubungan dengan kualitas tidur pada mahasiswa fakultas keperawatan Universitas Airlangga didapatkan ternyata stress juga dapat mempengaruhi kualitas tidur seseorang.

Hasil riset ini menunjukkan adanya hubungan antara kualitas tidur terhadap kebugaran jasmani, meskipun koefisien korelasi menunjukkan pada kategori rendah. Menjaga kualitas tidur sama halnya menjaga kebugaran jasmani. Tingkat kebugaran jasmani tidak hanya disebabkan oleh faktor kualitas tidur. Olahraga ataupun aktivitas fisik dapat menunjang tingkat kebugaran jasmani.

Kebugaran jasmani yang baik dapat bermanfaat secara fisik maupun psikologis di lingkungan kampus. Beberapa penelitian menunjukkan siswa yang bugar memiliki prestasi yang baik. Bugiarto (2009) menyatakan bahwa kebugaran memiliki hubungan yang signifikan dengan prestasi belajar siswa, ketika kebugaran siswa rendah dapat dipastikan prestasi belajar siswa juga rendah. Hal tersebut diperkuat oleh penelitian Sawunggaluh (2016) bahwa terdapat hubungan yang signifikan antara kebugaran, intelegensi, dan pergaulan teman sebaya dengan pencapaian prestasi. Hal ini dikarenakan faktor psikologis siswa yang kurang bugar akan lebih sulit menerima ilmu dibanding siswa yang memiliki kebugaran yang baik.

\section{KESIMPULAN DAN SARAN}

Kebugaran jasmani memiliki hubungan yang rendah dengan kualitas tidur. Hasil pebnelitian ini merupakan masukkan bagi para mahasiswa khususnya mahasiswa tingkat akhir agar selalu menjaga kualitas tidurnya dengan cara melakukan aktivitas fisik yang rutin sehingga dapat meningkatkan tingkat kebugaran jasmani. Tingkat kebugaran 
jasmani yang baik membawa dampak positif terhadap prestasi belajar mahasiswa.

\section{DAFTAR PUSTAKA}

Buysse, D.J., Reynolds, C.F., Monk, T.H., Berman, S.R., Kupfer, D.J. (2000). The Pittsburgh Sleep Quality Index (PSQI). In Rush, J. et al. Handbook of Psychiatric Measures. American Psychiatry Association. Washington DC.

Asmadi. (2008). Teknik Prosedural Keperawatan: Konsep dan Aplikasi Kebutuhan Dasar Klien. Jakarta: Salemba Medika.

Bugiarto, S. (2009). Hubungan Antara Tingkat Kebugaran Jasmani dengan Prestasi Belajar PAI Siswa Kelas VI SD Negeri Pakahan I Jogonalan Klaten. Universitas negeri Yogyakarta.

Erwinanto, D. (2017). Hubungan Antara Tingkat Aktivitas Fisik dengan Kebugaran Jasmani Siswa Kelas X Tahun Ajaran 2016/2017 Di SMK Muhammadiyah 1 Wates Kabupaten Kulon Progo DIY. Universitas Negeri Yogyakarta.

Hanief, Y. N., \& Himawanto, W. (2017). Statistik Pendidikan (1st ed.). Yogyakarta: Deepublish. Retrieved from https://books.google.co.id/books?hl=en\&lr=\&id=jfZRDwAAQBAJ\&oi =fnd\&pg=PR6\&ots=xTo6mjk_X9\&sig=elVLtbtiekM2wiauYbKkJRDC04\&redir_esc $=y \# v=0 n e p a g e \& q \& f=f a l s e$

Iqbal, M. D. (2017). Hubungan Aktivitas Fisik Dengan Kualitas Tidur Mahasiswa Perantau di Indonesia. Jurnal Pendidikan Jasmani Kesehatandan Rekreasi, 6(11), 227-234.

Nugroho, T. S. (2016). Perbedaan Kualitas Tidur pada Remaja yang Mengalami Obesitas dan Tidak Mengalami Obesitas di SMAN 2 Demak. STIKES Ngudi Waluyo.

Rizqia, N. S., \& Hartati, E. (2012). Pengalaman Mahasiswa Yang Mengalami Insomnia Selama Mengerjakan Tugas Akhir. Jurnal Nursing Studies, 1(1), 231-236. Retrieved from http://ejournals1.undip.ac.id/index.php/jnursing

Sarfriyanda, J. ', Karim, D. ', \& Dewi, A. P. (2015). Hubungan Antara Kualitas Tidur dan Kuantitas Tidur Dengan Prestasi Belajar Mahasiswa. Jurnal Online Mahasiswa (JOM) Bidang IImu Keperawatan, 2(2), 1178-1185. Retrieved from https://jom.unri.ac.id/index.php/JOMPSIK/article/view/8282

Sawunggaluh, P. N. (2016). Hubungan Tingkat Kebugaran Jasmani, Intelegensi. dan Pergaulan Siswa dengan Pencapaian Prestasi Kelas XI SMA Negeri 1 Kalibawang Kabupaten Kulonprogo Tahun 
2015/2016. Pendidikan Jasmani Kesehatan Dan Rekreasi, 1(1), 39.

http://journal.student.uny.ac.id/ojs/index.php/pjkr/article/view/2340/2 020

Sulistiyani, C. (2012). Beberapa Faktor Yang Berhubungan Dengan Kualitas Tidur Pada Mahasiswa Fakultas Kesehatan Masyarakat Universitas Diponegoro Semarang. Jurnal Kesehatan Masyarakat, 1(2), 280-292. https://doi.org/10.1007/s13398-014-0173-7.2

Sutri, S. (2014). HUBUNGAN AKTIFITAS FISIK DENGAN KESEGARAN JASMANI PADA REMAJA PUASA. Universitas Muhammadiyah Surakarta.

Wirnantika, I., Pratama, B. A., \& Hanief, Y. N. (2017). Survey Tingkat Kebugaran Jasmani Siswa Kelas IV SDN Puhrubuh I dan MI Mambaul Hikam di Kabupaten Kediri Tahun Ajaran 2016/2017. Jurnal SPORTIF: Jurnal Penelitian Pembelajaran, 3(2), 240. https://doi.org/10.29407/js_unpgri.v3i2.11898

World Health Organization. (2010). Global Recommendations on Physical Activity for Health. Switzerland: WHO Press.

YI, H., SHIN, K., \& SHIN, C. (2006). Development of the Sleep Quality Scale. Journal of Sleep Research, 15(3), 309-316. https://doi.org/10.1111/j.1365-2869.2006.00544.x 